\title{
'You have to change, the curriculum stays the same': decoloniality and curricular justice in South African higher education
}

\begin{abstract}
This paper reports on a study that focuses on students from rural areas of South Africa and their experiences of higher education. These students have attracted little attention in widening participation research in South Africa, despite being one of the most marginalised groups (Mgqwashu 2016a). The paper, drawing on the experiences of student co-researchers and using the concepts of decoloniality and curricular justice as a theoretical framework, argues for greater acknowledgement of epistemic reciprocity in curriculum development as a way to ensure more socially just curricula. Findings illustrate the importance that students attribute to being able to relate to curricula that reflect their experiences, curricula that they do not experience in higher education. Students report feelings of marginalisation, lack of recognition of the importance of knowledge and skills developed in their communities and their relevance to higher education together with the challenges they face accessing and engaging with the curriculum.
\end{abstract}

Keywords: rurality, higher education, curriculum development, curricular justice, decoloniality, epistemic reciprocity

\section{Introduction}

The words quoted in the title of this article were spoken by a student co-researcher participating in the (name removed) project involving three South African and two UK partner universities. The project's overall aim was to investigate how prior cultural and educational experiences influence the higher education trajectories of students from rural areas in South Africa, including their access and transition to higher education. The research addresses a knowledge gap and in so doing speaks to a concern expressed by Mgqwashu (2016a) that, despite being one of the most marginalised groups, there is 
relatively little research on students from rural areas. (although see Walker \& Mathebula 2019 and Mathebula, 2019). The (name removed) project investigates how students from rural contexts in South Africa negotiate the transition from rural home, school and community to higher education and how these negotiations influence their trajectories through higher education in South Africa. We investigated the practices that shape approaches to learning of students from rural areas in universities and the challenges they face in higher education curricula, which remain infused with colonial and apartheid knowledge and epistemologies.

This paper focuses specifically on the findings from the project that relate to issues of curriculum. Drawing on the experiences of student co-researchers and using the concepts of decoloniality and curricular justice as a theoretical framework, we argue for greater acknowledgement of epistemic reciprocity in curriculum development as a way to begin to address epistemicide (de Sousa Santos 2014) and linguicide (see wa Thiong'o 2009; Ndlovu-Gatsheni 2015) to develop more socially just curricula. We use the term epistemic reciprocity (Fricker 2015) to refer to curriculum development that engages explicitly with multiple knowledges, bringing them into dialogue with each other.

We begin by describing, briefly, the South African higher education context, in particular access and rurality issues. We explain the key concepts that we are using before describing the research project and its methodology. We then use the findings to illustrate the importance of decoloniality and curricular justice in South Africa based on a deep understanding of student experiences.

\section{Higher education and widening participation in South Africa}


Widening participation has been a major and ongoing concern in South Africa subsequent to the 1994 democratisation but the adequacy of the widening access process in numeric terms has been challenged (Badat nd; Leibowitz and Bozalek 2014; Cooper 2015). Of equal concern has been the lack of academic achievement of students from non-traditional backgrounds (Scott, Yeld and Hendry 2007; CHE 2016). Academic developers and policy makers in South Africa often use the term epistemological access (Morrow 2007) to describe how students' prior knowledge and experience are not recognised in higher education. This focus on epistemological access, or lack thereof, has emphasised mainly a deficit or under preparedness of the student, rather than the inadequacy and inappropriateness of the curriculum to meet her/his needs. Since 1994 there has been little change in the curriculum with most curricula continuing to be informed by colonial epistemologies (Heleta 2016; Le Grange 2016). In 2015 the need for transformation in South Africa was foregrounded by the student protests calling for the decolonisation of the curriculum, generally framed with references to race, and occasionally social class, although these are often integrated (Badat nd). For Chetty and Knaus (2016), however the student protests are a reflection of class struggle. This is evident in research indicating that only $15 \%$ of the $60 \%$ of black students who enter higher education complete their studies (Le Grange 2016). There is a gap in the literature in South Africa on the influence of rurality on students' achievement and participation in higher education. This has been discussed recently in relation to higher education institutions themselves (Leibowitz et al 2015; Walker and Mathebula 2019). Leibowitz (2010) suggests that the majority of student testimonies about prior learning experiences showed how rurality combined with race co-produced the repertoires in terms of practice, literacy and values that the students used to negotiate higher education. An influential study of 'disadvantaged' students in higher 
education in South Africa found that a multiplicity of factors affect transitions from rural areas, including geography, financial resources, schooling, language and 'other socio-cultural factors' (Jones et al 2008). Jones et al (2008) suggest that it is not only the students who are disadvantaged, but the institutions that are not prepared to support their needs. Ndebele (1995) also questioned to what extent large numbers of students are 'disadvantaged', and whether it is the institution and its dominant ethos that is in some measure 'disadvantaged'. Our study took account of these perspectives, as we wanted to consider the strengths that students bring to university, focusing specifically on their experience of the curriculum and modes of teaching delivery.

\section{Rurality in South Africa}

Rurality is difficult to conceptualise. It is spatial and contextual (Green and Reid 2014), may be demographic, geographic and cultural (Roberts and Green 2013), or may be defined 'empirically' as having sparsely populated areas and ontologically as 'a category and set of experiences' (Moreland, Chamberlain and Artaraz, 2003, 56). In South Africa, space is a deeply political matter due to the displacement effects of apartheid; 'rurality as a concept reflects the broader history of colonialism and dispossession' (Walker and Mathebula 2019,3). The relationship between race, geography, land and rurality is further underscored by Gordon $(2015,163)$ who refers to a 'geography of race' in which 'white populations have more geographical space than people of colour...'. One of the social categories most marginalised and affected by historical inadequacies is that of rurality, especially as it interrelates with race and ethnicity, both in South Africa and in other Southern African countries. Ideas of rurality are typically concerned with deprivation and deficiency including, among others, isolation, poverty, disease and neglect. These perceptions, however, do 
not reflect accurately heterogeneous experiences of rurality and the multiple ruralities that exist. For South Africa, Leibowitz (2017) draws attention to the need to also consider the interrelatedness of urban and rural areas in defining rurality as a construct for research in terms of the implications of how people understand their own identities and affiliations, as rural, urban or as both intersecting. Fataar and Filies (2016), writing about rural working-class students in South Africa, challenge the conceptions that they lack the necessary cultural capital for educational success, showing how learners maximise their family and community resources in their quest for success. 'The point is that students are not passive spectators or "deficient rural students" - they have assets that they might mobilise if the conditions of possibility allow' (Walker and Mathebula $2019,5)$.

It is difficult to locate clear statistics for the number of students from rural areas in higher education in South Africa as they tend to be grouped together with disadvantaged students (Czerniewicz and Brown 2014). They are, however, disproportionately represented i.e. the numbers are fewer than they should be. Moreover, Walker and Mkwananzi, (2015) claim that a new form of social exclusion in dealing with access to higher education in South Africa has emerged, that of increasing access without increasing the success of underprepared undergraduates from poorer backgrounds. A serious concern, according to Roberts and Green (2013) is that educationists assume that rural students need to become less rural, or 'other' than what they are in order to succeed. This is supported by Mgqwashu (2016b) who claims that higher education encourages students to turn against rural life, contributing to epistemicide and linguicide. Epistemicide refers to the destruction of indigenous knowledge forms as a result of the hegemony of Western knowledge forms (Leibowitz 2017). Similarly 
linguicide refers to the destruction of indigenous languages through privileging the languages of the colonisers (see wa Thiong'o 2009).

Much literature of direct relevance to rurality and education with a backdrop of colonisation and social injustice is not, however, signposted as being about rurality, but is about indigeneity, relationship with the land, colonialism, or about local knowledge versus formal knowledge. Place as a concept is increasingly of interest to literacy, environmental, indigenous and rural education (Green and Reid 2014). A key observation is that rurality does constitute a form of disadvantage, however several writers are at pains to point out that there are advantages to rural life in some cases (Stokes, Stafford and Holdsworth n.d.) for example, that parents have more control over what their children are exposed to or that smaller class sizes allow for more intimacy. However, while classes in rural areas may be smaller in other countries, in South Africa this is less likely to be the case. Schools in the rural areas are typically poorly resourced and have relatively high teacher-student ratios (du Plessis and Mestry 2019). Similar claims are that people living in rural areas are resilient and determined, despite the constraints, to pursue a 'better life' (Randall, Clewes and Furlong 2015). 'Spatial blindness' is another source of concern, as it assumes students from metropolitan and rural areas have the same needs.

Most of the widely available literature on rurality (in English) comes from Australasia, North America and the UK. Inevitably, this skews the perspectives, given the varied conditions that pertain, for example in Africa or Asia. Whether a country has the majority of its population as rural can also affect the reporting, since if the majority of a country's population is rural (85\% for Malawi as opposed to South Africa where only $35 \%$ of the population is rural)(tradingeconomics.com) this can affect the concern with and depiction of rurality. There may also be differences to do with the histories of 
regions, for example whether rurality is affected predominantly by colonialism and apartheid (South Africa or Namibia) or a combination of colonialism and neoliberalism, for example Canada or Australia, where colonialism affected the small first nations populations, with the white rural populations feeling the brunt, more recently, of neo-liberal policies. By contrast, in South Africa, policies of dispossession pursued by successive white governments prior to 1994 resulted in impoverished socio-economic status for black people generally.

In mapping the student co-researchers' home locations we found that almost all were from areas that were previously designated homeland areas. The Bantustan system of homelands was established through a series of oppressive legislation and policies including the Land Acts of 1913 and 1936. These homelands served as reservoirs of cheap labour and dumping zones of unwanted labour. The homelands fell under traditional tribal leaderships and occupied only $14 \%$ of the land compared to the $86 \%$ set aside for white occupation, parks, military ranges and other state uses (Human Sciences Research Council 2005). These acts of dispossession entrenched impoverished socio-economic status and disorganised family life for the re-tribalised blacks in the Bantustans. Dispossession constructed both resource disadvantage at the community level and resource deficits for schools located in these communities.

\section{Decolonisation/decoloniality}

'What do we do with a difficult past in the context of a contested present'? (Case 2017, 9) and, as Mbembe $(2016,32)$ claims, 'there is something profoundly wrong when, for instance, syllabuses ( $\mathrm{sic}$ ) designed to meet the needs of colonialism should continue well into the liberation era'. We believe, therefore, that there is a need to 'decolonize the university' by reforming it 'with the aim of creating a less provincial and more open 
critical cosmopolitan pluriversalism' (ibid, 37). Calls for the decolonisation of the university and curriculum in South Africa have been occurring for some time, drawing on the work of those such as Franz Fanon, Steve Biko, Ngu g1 wa Thiong'o and Edward Said. In any discussion, however, of decolonisation of the curriculum in South Africa, one of the complexities is to determine whether the propositions are for an Africanised curriculum i.e. a curriculum that rejects all Eurocentric ideas (for example Msila and Gumbo 2016) or one that weaves together African indigenous knowledges and Eurocentric concepts. One proposal is that decolonisation of the curriculum entails a transformative process; one which does not necessarily involve eradicating Western knowledge but, rather involves 'decentring it' (Le Grange 2016, 6) or 're-centring' African epistemologies (Mbembe 2015; Prinsloo 2016). As Mbembe (2016, 35) asserts, decolonisation of the curriculum 'is not about closing the door to European or other traditions. It is about defining clearly what the centre is.' Placing Africa firmly at the centre, Heleta $(2016,5)$ argues that 'universities must completely rethink, reframe and reconstruct the curriculum and bring South Africa, Southern Africa and Africa to the centre of teaching, learning and research. This in no way means that decolonisation will lead to localisation, isolation or only Africanisation of the curriculum'. We believe, however, that it does mean ensuring appropriate pedagogy for students, particularly students from disadvantaged backgrounds. As will be shown in this paper, analysis of our data points to a sophisticated understanding of decolonisation and a clear preference for defining what should be at the centre of a curriculum by bringing different knowledges into dialogue through epistemic reciprocity. We argue for the centrality of the curriculum in any discussion of access and equity, including retention, whether it be in South Africa or Europe. We can relate this to Motsa's $(2017,30)$ extended definition of epistemicide - "the "zone of being" (colonial) syllabus has been 
insidiously divisive, officious and not inclusive to the knowledge systems of the global South, which, in turn have been perceived as pagan, mystic, non-scientific, incompetent'.

It is important to stress that decolonising the curriculum ought to pay attention to what is taught as well as how is it taught and learnt. The data presented in this paper speak to the challenges student co-researchers face as a result of the domination of English as a medium of instruction, supportive of Dastile and Ndlovu-Gatsheni's (2013) argument that the continued use of colonial languages perpetuates the marginalisation of subjugated groups. The issue of how we teach in higher education also raises questions about conventions, for example academic literacies and how these are experienced by students (Webbstock 2017). Boughey $(2002,2013)$ explains the historical issues of language teaching in South Africa and that academic literacies and academic development are inflected by social and cultural approaches. During and after the apartheid years black students were considered as speakers of an additional language and taught to speak and write only functionally, positioning them as users of English as a second language, ignoring their potentially differential struggles (Boughey 2013, 1). Following Lea and Street (1998) and with a focus on South Africa, Boughey (2013) argues there are home and school-based literacies, which in South Africa intersect with race. In order to be a successful student, one needs to learn higher education literacies. Boughey (2013) mentions a student who has been taught at school to cut and paste text from written authorities but discovers that doing so in higher education is seen as a sign of incapacity and ignorance. Initially, students from rural areas might be hampered by the functional ways they were taught English, as access to powerful knowledge and expression of it depend on appreciating and working with language as situated culturally_and socially, in addition to learning and adopting higher education literacies 
practices. One needs to question, however, whose 'powerful knowledge' one is being given 'access' to.

According to Ndlovu-Gatsheni $(2015,458)$ 'decoloniality materialized at the very moment in which the slave trade, imperialism, and colonialism were being launched. It materialized as resistance, thought and action'. He continues:

Decoloniality is born out of a realization that the modern world is an asymmetrical world order that is sustained not only by colonial matrices of power but also by pedagogues and epistemologies of equilibrium that continue to produce alienated Africans ... Schools, churches and universities in Africa are sites of reproduction of coloniality.

Ndlovu-Gatsheni $(2015,489)$ argues that to date instead of African universities 'we have 'universities in Africa' which 'continue to poison African minds with research methodologies and inculcate knowledges of equilibrium. These are knowledges that do not question methodologies as well as the present asymmetrical world order' (489). The methodological approach adopted in our study, described later in the paper, was chosen deliberately to address this criticism of uncritical acceptance of methodologies. Finally 'decolonizing the mind speaks to the urgency of dealing with epistemicides and linguicides. Moving the centre addresses the problem of EuroNorth American centrism.' (Ndlovu-Gatsheni 2015,493). In our research - we challenged ourselves to distinguish between 'decolonisation' and 'decoloniality' and, in our data, to look for examples of where we considered comments/experiences to be redolent of a continuing colonial mindset and/or to illustrate decoloniality. These ideas are now developed in the following section through the concept of curricular justice.

\section{Curricular Justice}

In 2016, when we submitted the project proposal, \#Fees Must Fall and \#Rhodes Must Fall were making headlines worldwide. Students were clamouring for significant 
changes in South African universities, including decolonisation of curricula that they argued were not fit for purpose.

As, a research team, we have been dedicated, for several years, to developing curricula that are more equitable and socially just. It seemed imperative, therefore, to incorporate the exploration of such issues into the aims of the research. Given the extensive marginalisation of students from rural contexts in South Africa, as we explained earlier in this paper, exploring the challenges they face when they encounter curricula that continue to be imbued with colonial epistemologies, was entirely apposite; a core aim of the project was to propose inclusive alternatives that build on all student experiences. Connell's (1992) notion of 'curricular justice' is based on 'how social effects are embedded in the curriculum-as-practised' (138) and that the selection of 'knowledge' for a curriculum is 'not done in heaven by a committee of epistemological angels' (137). Connell (2017) argues that curriculum change in relation to southern and postcolonial theory is underdeveloped and needs to address the marginalisation or discrediting of cultural, religious and linguistic traditions. We use 'curricular justice' to help frame the data analysis because we agree that the 21 st century university system continues to be inequitable, embedding a 'narrow knowledge system that reflects and reproduces social inequalities on a global scale' (Connell 2017, 10) and 'a Eurocentric curriculum prevails everywhere' (ibid, 6). In order to challenge the prevalence of Eurocentric curricula, the voices of those who are most usually exemplified in access and equity agendas, must be heard and attended to. This necessitates 're-making curricula in Northern as well as Southern universities' (Comaroff and Comaroff, 2012, 13).

We do not propose that curricular justice replaces or is superior to decoloniality and the struggle against epistemicide but what is attractive to us is that it proposes a critique of 
culture, creating space for dialogue and for reframing learning as conversations between equals.

\section{Methodology}

A participatory methodology was employed in this study, where student co-researchers researched their own lives and contributed to shaping the direction of the research. The study drew on the principles of participatory research and co-operative inquiry and so worked directly with students as co-producers of knowledge. The methodology was also grounded in narrative principles that focus on eliciting ideas and beliefs formed in contexts (Daiute 2014; Townsend and Weiner 2011) such as rural schooling or homes as well as university. It can be argued that such an approach aspires to be a 'decolonizing' mode (Bozalek and Biersteker 2010), by aiming to avoid a deficit positioning of students as participants or subjects within the study and instead of researching on them, to research with them. As indicated earlier, by adopting such an approach, we sought to address the criticisms of methodologies made by those such as Ndlovu-Gatsheni (2015). However, despite our efforts to ensure a certain level of equity and participation in the study, it is important to recognise the power differentials that continue to play out in any research project and acknowledge the limitations for coresearchers in being able to shape its aims and direction.

Second year undergraduates from rural backgrounds were recruited as co-researchers, developing a model based on previous research in the UK (Timmis and Williams 2013; Timmis et al 2016) and in South Africa (Rohleder and Thesen 2012; Leibowitz et al. 2012). Fieldwork was conducted at three universities. These were 'Urban', a 'comprehensive' university with a balanced focus on research, teaching and technology, 'Town', a rural, research-led and 'previously advantaged' university, and 'Local' a 
rural, teaching-led, 'previously disadvantaged' university. These institutions were chosen to represent different types of universities where rural students are strongly represented and are in different parts of South Africa.

There were 24 co-researchers from each of the three institutions recruited, with a balance studying science, technology, engineering and mathematics (STEM) and Humanities and education programmes, 72 co-researchers began and 64 co-researchers continued throughout. The majority were born in South Africa with one from, Lesotho, a neighbouring Southern African country. There was a need to acknowledge the complexities of rurality and what 'coming from a rural background' actually means. The categories provided by the South African Statistics Agency, specifically from their publication investigating appropriate definitions of urban and rural areas (Statistics South Africa 2003) were used to inform the research. We adopted the categories of 'formal rural' (e.g. farm, small holding) and 'tribal area'(e.g. tribal settlement which tends to be located in the areas previously designated homelands under Apartheid or village (not in a tribal area) to differentiate the types of rural areas. Most of the participants were from areas previously designated homelands. Rurality is both spatial and non-spatial, as explained earlier in the paper, and so we conducted sampling using both types of indicators. For example - we defined a rural area in terms of low population density but also in terms of the civic and commercial amenities available, including schools. This is because some areas, particularly tribal areas, may have a population density equivalent to some urban areas in South Africa. Of itself, therefore, population density is not sufficient to determine a rural area or background (Laldaparsad 2006). We aimed for students who had lived and attended school in a rural area (formal rural or tribal area) for at least the first sixteen years of their lives. 
Data were generated by the student co-researchers who participated in seven face-toface workshops over approximately nine months. These workshops included group discussions and activities such as drawing, and mapping. Each student co-researcher was given an iPad and they created longitudinal, personal accounts and representations of everyday practices in their rural communities and in their university academic and social lives by collecting a series of digital artefacts using an App called Evernote (or in some cases Google Docs). These included diary entries, audio recordings, drawings, photographs and other artefacts, chosen by co-researchers to represent their lives. Multimodal methods are helpful in reducing reliance on writing and language, especially in a second language (Rohleder and Thesen 2012) and are a further example of our desire to guard against perpetuating epistemicide and linguicide. Co-researchers received initial training and were supported throughout the data collection period, creating composite narratives of their trajectories in the final session. They subsequently participated in preliminary data analysis workshops, discussions and networking between the co-researchers from the three universities.

The qualitative data set includes over 72 discussion workshop transcripts, digital documentaries (collections of artefacts) and composite narratives created by student coresearchers. Data analysis was conducted inductively, multimodally and theoretically. A systematic thematic and multimodal analysis of all data types was conducted, which produced a total of 60 themes (Ritchie and Spencer 1994). Thematic analyses continued through an on-going, iterative process involving whole team sessions including one with student co-researchers, as indicated earlier. Sessions with the team and co-researchers facilitated deeper, theoretically informed, multi-layered interpretations of the data (Pink 2013). 
The research study also involved individual interviews and focus groups with senior leaders and academics at each of the three universities, including the Deputy Vice Chancellors for learning and teaching and the Deans of Students (or equivalents), academics and academic developers. Interviews explored with institutional senior leaders how institutions manage access and support under-represented students and their perceptions of issues facing students from rural contexts. Focus groups investigated support for students from rural areas, inclusivity and diversity within the curriculum and pedagogic practices and contradictions and tensions. Data from student co-researchers were used in the formation of suitable questions for these activities.

The rights and responsibilities of all members of the team including student coresearchers were negotiated and agreements were reached collaboratively. This ensured that ethical thinking and ethical mindfulness informed the research process throughout. Full ethics applications were submitted and approval granted at all the universities involved. Informed consent was sought and obtained from all those taking part. Coresearchers were asked for their consent at the outset and they were specifically asked for consent for sharing their data more widely (for example images and documentaries produced). We developed a set of ethical principles to share with all members of the team, in particular the co-researchers. They were given opportunities to ask questions and to review the scripts once transcribed.

\section{Research Findings}

In line with the focus of this paper, we now draw on some of the findings from the research focusing on the complexities of language, complexities of current curricula and ways in which curricula may be revised using the concepts of decoloniality and 
curricular justice. Verbatim quotes are given codes that indicate the source of the data, the date collected and the gender of the speaker.

\section{Decoloniality and Curriculum}

The experiences of student co-researchers speak to the challenges of studying in a higher education system that remains colonial. Many argued that their rural knowledges and practices were not acknowledged in higher education and they associated higher education with 'westernisation', characterised by a denial of 'cultural values that we actually learn from the mountain' (discussion group, Town, 22.07.17 M). To some extent this supports the point made by Mamdani (2016)

Colonialism brought not only theory from the Western academy but also the assumption that theory is produced in the West and the aim of the academy outside the West must be to apply that theory. Its implication was radical: if the making of theory was truly a creative act in the West, its application in the colonies became the reverse, a turnkey project (Mamdani 2016, 81).

As indicated earlier, there is much previous research that supports this perspective and, in our own research, many examples of co-researchers resisting the continuing coloniality in higher education. There is a sense of Western knowledge and learning and teaching first downplaying then supplanting their own culturally inflected understanding, which leads to a preference for the ways of home and also a profound sense of loss;

'...there's a lot of things that are done culturally that have meaning. But then slowly and surely we are ... letting go of all the knowledge, because ... sometimes we don't even engage to ask our parents "why do you slaughter the cow the way you do? Why is it that this piece would go to that family? Why is it that we must follow this certain procedure when doing things?" So we are not interested 
enough and ... by the time our parents die and our grandfathers die, it might end up in the next 20 years to come we would have lost all that indigenous knowledge we have acquired because now we are so influenced by the western way of doing things, urbanisation ... we are letting go of the critical things that make us African, the things that groom us, that give us our identity in our communities ... rurality has such deep knowledge ... when you are herding cows you'll find that a young boy who has not learned to count yet ... will ... learn to associate the patterns of the cows ....' (Discussion group, Local, 27.07.2017, M)

This is neither straightforward homesickness nor nostalgia, particularly for those student co-researchers who had already experienced a move from small, often poorly equipped local primary schools to rural boarding high schools. They acknowledge that they might have under-estimated their previous learning when in their rural context and that they did not take it seriously. They found such knowledge and practices overlooked in the curriculum both in high school and then in university. The comment illustrates the importance of developing curricula that bring different knowledges into dialogue and their potential to address epistemicide.

Some of the co-researchers indicated their realisation that previous learning is both formal and informal and is re-described at university, understood differently, or perhaps at a different level. One student described learning in the home as the foundation upon which further learning builds. 'So I feel like learning from home it is a foundation actually and the wall of learning. I feel like University and the school just finish up the work by putting a roof' (Evernote Town, 1.04. 2017, F).

Several stories were about caring for cows. These were highly practical and symbolic as they detailed counting cows, realising their immense value to the community and showing responsibility towards other humans and creatures.

'...learning how to count as a child has duties, like taking cows to graze and fetching the cows by that time you don't even know how to count, but you 
know that all the cows are there when you look at them ... you memorise them with their colours, you also memorise the position or type of horns they have so you recognise the cows according to their horns, their colours and you never go wrong. You know when you look at a whole lot of them if one cow is short and which cow according to the horns is not there even though you don't know how to count...' (discussion group, Local, 1.06. 2017, M.)

Underlying co-researchers' recognition of what is underestimated, lost or ignored in high school and then most certainly in university, is a sense of entering quite a different culture where the rules and language are, at first, confusing. Subsequently, they realise the benefits of previous learning and of worldviews, behaviours and skills, which are rarely recognised, developed or rewarded in the curriculum they meet at university. The student co-researchers, aware of the possibility of losing their local knowledge, and modes of knowledge construction, some acquired from elders, some from everyday activities, urge that these be used, shared, recognised, kept alive in the university; 'we have this rich knowledge where we come from which is ezilalini (village). So basically I'm looking forward to using that knowledge to ... make that knowledge be accommodated here because ... we can learn a lot from what we had...' (discussion group, Town, 25.03.2017, M.)

Students find drawing on their prior knowledge and experience challenging, particularly when they need to align their experience with conventions of learning in higher education, such as the need to provide evidence:

'Sometimes, before the professor planted I felt like it [indigenous knowledge] wasn't acknowledged, I felt like they would say ... you see how science flows with experience, they want facts, they want to prove if you say this happened doing this and this, they will say prove it, that's science. If I say my father does 
the ... they say how so it's not acknowledged' [even though the procedures are similar] (discussion group, Town 12. 08. 2017, F.)

In the quote below the student co-researcher highlights the importance of teachers ensuring that students' prior experience and knowledge is taken into consideration and built on in teaching and learning.

'To answer that I will say for example I'm doing Physical Science, I'm going to teach Physical Science, on the question papers when they make examples of scenarios those examples they use objects that are not available in most villages you find that learners have no idea what those things are, I think it would be best if they would take into consideration making use of those objects when making scenarios for example if they make use ok I can't think of a specific example at the moment but I believe if they can just learn what the learners know outside the classroom and try to make use of such thing because you'll find that the learner knows the answer but they don't understand what that thing is so that's how I think they can incorporate indigenous knowledge.' (discussion group, Urban, 5.4.2018, M.)

While the above quote illustrates students' call for curricular justice through a curriculum that acknowledges social experiences, the different perspectives and experiences that students have gained prior to university are not given the recognition or value that they believe they deserve. Other students, however, felt that one of their university teachers did acknowledge and see value in the knowledge that they were bringing:

'It just upgrades [the existing knowledge] but to add on that there was this other time Natural Science assess... we had to assess the soil ... but I was familiar with that thing because before at home you know when it's planting season, before we plant we crop rotating ... assesses the soil if it is good to plant spinach ... actually 
our professor he was impressed like he loved it' (discussion group, Town, 12. 8. 2017, F.)

\section{Language and the Curriculum}

Challenges of language and the continuing dominance of colonial languages in higher education (Connell 2017; Dastile and Ndlovu-Gatsheni 2013) were highlighted earlier. These authors argue that the discrediting of linguistic traditions and the continuing use of colonial languages perpetuate the marginalisation of non-white students and, we would add, those from rural contexts. Thus one of the most significant problems that our co-researchers highlighted was language. The dominant language of higher education in South Africa continues to be English but for the majority - if not all - of the co-researchers, English was not the language in which they had been educated prior to university. They did however write most of their final school examinations in English.
'About $90 \%$ of our subjects were written in English, but our teachers will try by all means to explain to us the concepts in our mother tongue and in that way we would just understand at instant. However, in varsity, things are different, English is the language that is used in the lecture rooms and is the most spoken language' (Evernote, Urban, 24.08.2017, M).

Students talked about how it was 'difficult to adjust to English

'Home language and schooling taught in isi-Xhosa. So it took me time to cope with that, to understand lectures but I managed because I involve myself with some people who can explain to me in my language so I can understand...' (discussion group, Town 22. 07. 2017, F). As a result, students looked to each other for help in being able to understand what was being taught and shared translations into the local shared language. Furthermore, the 
additional problem of accent and speed of talking in English, particularly in the case of white lecturers was highlighted as problematic by some of the student co-researchers.

'... the main problem is language ... most of the lecturers here at Town

University are white people, and ... it's really hard grasping something from a white person, like they are used to their own language ... your home language is isi-Xhosa, it's really, really hard to adapt, and they sometimes try to be very fast and you don't catch things.'

'One of the challenges of the language, as much as we are always like, we are trying with the English from back at school, the English language, you find that at some schools ... you speak English only when you go to the principal and some we don't speak English at all. So coming here, everyone was speaking English ... we felt like ... we were left behind, we didn't understand what they were saying...' (discussion group, Town, 22.07.2017, F.)

Students were also not familiar with disciplinary conventions and the terminology used became another level of language use to master.

I actually failed from Cell Bio... it is not hard, it is just that Cell Bio is not about you knowing information, it's about how you present your information and sometimes with the language it becomes like a barrier because sometimes you can't express yourself enough (discussion group, Town, 1.04.2017)

These multiple challenges of using English and gaining understanding of a new disciplinary language can mean that students are struggling to understand what they are reading and can also struggle in examinations.

If this dictionary was not there last year. I would not have survived. In all my studies I referred to it for thorough explanations. In psychology and linguistics I used it mostly because they require someone who has good English basic in order to understand properly. It makes it difficult to understand because if there's one difficult word, you won't understand the whole context of that passage.' (Evernote, Town, 11:08:2017:F) 
Significant challenges are faced by many of the co-researchers and it brings into sharp focus the difficulties of being able to adapt to using English very quickly, to understand what is being discussed in lectures and classes and also engage with complex disciplinary concepts and ideas in reading materials. Given these multiple challenges, the high dropout rates and the lower rates of progression of students can begin to be explained.

We also gained clear recognition, from our interviews with academic staff, of some of the challenges faced by students around language.

['Just to get your sense of how we may think or what we mean by rural student, and how they may differ from students who come from a city, a more urban area'] 'There are kind of two things ... the other thing is the languages. They would have been to schools where they have been educated in an African language and all of a sudden they are expected to do things in English.' (focus group, Education, Town, 16.4. 2018, F.)

'...Learning about language. This is an English university and for many of our students English is not their home language. It's a double world to overcome, a strange space and the way that you are doing it is you haven't even got the language proficiency that many of your peers have got and that can silence you because you might be embarrassed to speak because your accent is different or you haven't got the vocabulary...' (interview, Town, 13.4. 2018, Dean of Education)

There is additional language support available at each university and those students who take part in Foundation Programmes, which were introduced to address students' underpreparedness for university study as a result of inequities in the schooling system, have been useful in familiarising students with disciplinary concepts and help them use English in their academic studies. However, this does not address the more fundamental question of linguicide (Mgqwashu 2016). Furthermore, there needs to be a problematisation of 'academic literacies' as 'neutral', as argued by Boughey (2013) and 
to understand the socially constructed nature of such literacies and links to student identity.

'The argument starts from the premise that learners and learning are socially embedded, and that 'academic literacy' is not a value-neutral set of skills to be acquired, but that academic literacies, being socially constructed, can be experienced as colonial or alienating to students who are not privy to the hidden codes and meanings that actually underlie a so-called value-neutral discourse' (Webbstock 2017,4)

$\underline{\text { Recognising the socially constructed nature of academic literacies, therefore, and the }}$ challenges of English language usage and learning of new disciplinary language faced by the co-researchers lead us to conclude that such issues need to be foregrounded in ideas around curricular justice.

\section{Toward Curricular Justice?}

As is seen in this paper, the values of home and community inform the learning behaviours of students from rural contexts. Their views and experiences about community and the foundational learning that took place feature strongly in their comments. For some the opaqueness of the insider knowledge of what is expected coupled with the expectation that they challenge the authority of older adults such as teachers and lecturers, are experienced as new and alienating. They find out about the rules, the discourse, the technology, taking notes in large crowded lecture halls. They have to adapt to these practices and behaviours but their responses to these new and different ways of learning evidence an imaginative and systematic problem solving and persistence not always obvious, in their peers. The findings from our project indicate that it is usually the students who are making all of the effort to adapt, but the curriculum i.e. learning, teaching assessment and content could be revised to clarify and 
negotiate expected learning behaviours, develop and reward group learning, clarify and negotiate the modes of expression and discipline based forms of learning expected. The curriculum could be questioned, it could adapt so that diversity of learning behaviours are enabled. The co-researchers' insights about deficit models, the expected and often unclarified need for their own adaptation could feed into all the strengths they have developed in and derived from their rural contexts' worldviews and conditions of learning. These, when harnessed, support their successful learning. Inevitably most of the literature on decolonisation of the curriculum highlights the complexities of enacting it. As our findings illustrate, decolonising the curriculum to develop curricular justice is more than changing the content to make it more African or ensuring that examples/case studies etc. are drawn from Africa. The process involves the ongoing interrogation of those knowledges that are privileged and those that continue to be ignored, subordinated, dismissed, marginalised (Motsa 2017). Demands from the Rhodes Must Fall (RMF) collective included:

- Treating African discourses as the point of departure - through addressing not only content but languages and methodologies of education and learning -and only examining western traditions in so far as they are relevant to our own experience.

- Introduce a curriculum and research scholarship linked to social justice and the experiences of black people.

- Meaningfully interrogate why black students are most often at the brunt of academic exclusion (Luckett, 2016, 416)

The student learning narratives collected in our study not only reflect such demands but show how retaining and building on previous rural knowledge and learning offer an opportunity for a very rich diverse set of learning practices. In order to achieve this richness, curriculum development ought to foster epistemic reciprocity and learning has to be reframed as conversation. 


\section{Conclusion}

Content matters, in particular when a European-centred curriculum continues to dominate and define what counts as worthwhile knowledge and legitimate authority in South African texts and teaching; it matters in the context of the inherited curriculum, informed by apartheid and colonialism, in which only the more readily observable, offensive racism has been skimmed off the top (Jansen 1998). Our research was conducted in South Africa but it is important to recognise that the issues discussed in this paper are global. They have direct relevance to other Southern African and former colonial contexts and, perhaps, rather less direct but still critical, relevance to the colonisers (Leibowitz 2017). Although currently it is the student who feels that s/he has to change as 'the curriculum stays the same', the voices of students and, in our case, students from rural contexts can no longer be ignored. We acknowledge, of course, that the transition to higher education involves significant changes for all students, irrespective of their background but, when that background is at best unacknowledged and at worst dismissed as irrelevant, then it is difficult to explain such practices as anything but reflecting continuing coloniality. It is time that the curriculum - as well as the student - changed. Then, rather than have 'universities in Africa', there would truly be African universities.

\section{Acknowledgement}

The [name removed] project undertaken by Principal Investigators [names removed] with Co-Investigators [names removed]. We were accompanied on this project by 72 student co-researchers and 10 institutional researchers. We fully acknowledge their contributions. 
This work was supported by the Newton Fund, the Economic and Social Research Council (UK) and the National Research Foundation (South Africa) [ES/P002072/1].

\section{References}

Badat, S. n.d. Deciphering the meanings, and explaining the South African higher education protests of 2015- 2016. https://www.sahistory.org.za/archive/decipheringmeanings-and-explaining-south-african-higher-education-student-protests-2015-0 Boughey, C. 2002. 'Naming students' 'problems': an analysis of language related discourses at a South African university". Teaching in Higher Education 7 (3): 295-307. Boughey, C. 2013. "What are we thinking of? A critical overview of approaches to developing academic literacy in South African Higher Education”. Journal for Language Teaching. 47(2): 25-42.

Bozalek, V. and Biersteker, L. 2010 "Exploring Power and Privilege Using Participatory Learning and Action Techniques”. Social Work Education. 29(5): 551572.

Case, J.2017 Public higher education in peril? A view from down south. Centre for Global Higher Education Working Paper no.15.

Chetty, R. and Knaus, C.B. 2016 Why South Africa's universities are in the grip of a class struggle. The Conversation, http://theconversation.com/why-south-africas$\underline{\text { universities-are-in-the-grip-of-a-class-struggle-50915 }}$

Comaroff, J. and Comaroff, J.. L. 2012 Theory from the South: Or how Euro-America is evolving towards Africa. Boulder, Colo: Paradigm.

Connell, R. 1992 “Citizenship, Social Justice and Curriculum”. International Journal of Sociology of Education 2 (2): 133-146. 
Connell, R.W. 2017 "Southern theory and world universities." Higher Education Research and Development 36 (1): 4-15

Cooper, D. 2015 "Social justice and South African university student enrolment data by 'race', 1998-2012: from 'skewed revolution' to 'stalled revolution'”. Higher Education Quarterly, 69 (3): 237-262

Czerniewicz, L and Brown, C. 2014. The habitus and technological practices of rural students: A case study. South African Journal of Education, 34 (1)

Daiute, C. 2014 Narrative inquiry: A dynamic approach. Los Angeles: Sage. Dastile, P.N.and Ndlovu-Gatsheni, S.J. (2013) "Power, knowledge and being: Decolonial combative discourse as a survival kit for pan-Africanists in the $21 \mathrm{st}$ century", Alternation, 20 (1): 105-134.

De Sousa Santos, B 2014. Epistemologies of the South: Justice Against Epistemicide. Boulder, Colorado: Paradigm Publishers.

\section{du Plessis, P. and Mestry, R. 2019 Teachers for rural schools - a challenge for South}

\section{Africa. South African Journal of Education. 39 (suppl.1). s1-s9.}

\section{https//dx.doi.org/10.15700/saje.v39ns1a1774}

Fataar, A. and Fillies, H. 2016. Die leerpraktykvorming van hoerskoolleerders op 'n plattelandse werkersklasdorp. Litnet Akademies 13 (2): 377 - 402.

Fricker,M, 2015 Epistemic contribution as a central human capability. In G.Hull (Ed.) The Equal Society (pp.73 -90). Cape Town: UCT Press.

Green, B. and Reid, J. 2014. Social cartography and rural education: researching space(s) and place(s). In: White, Simone and Corbett, Michael (eds) 2014. Doing Educational Research in Rural Settings: Methodological issues, international perspectives and practical solutions. Abingdon: Routledge (pp26 - 40)

Gordon, L. 2015. Race and justice in higher education: Some global challenges with attention to the South African context. In: P. Tabensky and S. Matthews (eds) Being at 
home: Race, institutional culture and transformation at South African higher education institutions. Pietermaritzburg: UKZN Press

Heleta, S. 2016. "Decolonisation of higher education: Dismantling epistemic violence and Eurocentrism in South Africa”. Transformation in Higher Education, 1(1): 1-8. Human Sciences Research Council-Education Policy Centre (HSRC-EPC) 2005. Emerging voices: A report on education in South African rural communities. Commissioned by the Nelson Mandela Foundation. Cape Town: HSRC Press. Jones, B., Coetzee, G., Bailey, T., and Wickham, S. 2008. Factors that facilitate success for disadvantaged higher education students: An investigation into approaches used by REAP, NSFAS and selected higher education institutions. Athlone: Rural Education Access Programme.

Laldaparsad, S. 2006. Statistical approaches for classifying and defining areas in South Africa as "urban"e and "rural". University of Witwatersrand. Retrieved from http://wiredspace.wits.ac.za/handle/10539/3897 Le Grange, L. 2016. ’Decolonising the university curriculum: leading article”. South African Journal of Higher Education, 30(2): 1-12.

Lea, M.and Street. 8. 1998. Student writing in higher education: An academic literacies approach. Studies in Higher Education 23 (2): 157-171.

Leibowitz, B. 2017. "Cognitive justice and the higher education curriculum”. Journal of Education, 67.

Leibowitz, Brenda no date. Power, knowledge and learning: A humble contribution to the decolonisation debate.

Leibowitz, B. and Bozalek, V. 2014 Access to higher education in South Africa: A social realist account. Widening Participation and Lifelong Learning. 16 (1): 91 - 109. http://wplljournal.metapress.com/link.asp?id=X7243U561274. 
Leibowitz, B., Swartz, L., Bozalek, V., Carolissen, R., Nicholls, L., and Rohleder, P. 2012. Community, self and identity: educating South African university students for citizenship. Cape Town, South Africa: HSRC press.

Luckett, K. 2016 "Curriculum contestation in a post-colonial context: a view from the South”. Teaching in Higher Education 21 (4); 415-428.

Mamdani, M. 2016 "Between the public intellectual and the scholar: decolonization and some post-indigenous initiatives in African higher education". Inter-Asia Cultural Studies 17 (1); 68-83.

Mathebula, M. 2019 "Recognising poor black youth from rural communities in South Africa as epistemic contributors". CRiSTAL 7 (1): 64-85 DOI: 10.14226/cristal.v7i1.181.

Mbembe, A.2015. Decolonizing knowledge and the question of the archive. Aula magistral proferida.

Mbembe, A. 2016. Decolonizing the university: New directions. Arts and Humanities in Higher Education, 15(1): 29-45.

Mgqwashu, E. 2016 Education can't be for the 'Public Good' if Universities ignore rural life. The Conversation, 16 March 2016. Retrieved from https://theconversation.com/education-cant-be-for-the-public-good-if-universitiesignore-rural-life-56214.

Mgqwashu, E. 2016. 'In South Africa, what are we supposed to do away with when we decolonise the curriculum?' open Democracy, 1 March 2017, Retrieved from https://www.opendemocracy.net/wfd/emmanuel-mgqwashu/in-south-africa-what-arewe-supposed-to-do-away-with-when-we-decolonise-curriculum 
Moreland, N, Chamberlain, J., and Artaraz, K. 2003. Rurality and higher education: A conceptual analysis. In: M. Slowey and D. Watson (eds) Higher Education and the Lifecourse. Maidenhead: OUP and SRHE (pp 51- 66).

Morrow, W. E. 2007. Learning to teach in South Africa. Cape Town: HSRC p Motsa, Z. 2017 When the lion tells the story: a response from South Africa. Higher Education Research and Development, 36 (1) 28-35

Msila, V. and Gumbo, M. (Eds) 2016. Africanising the curriculum: Indigenous perspectives and theories. Stellenbosch: SunMedia.

Ndebele, N. 1995 Maintaining domination through language. Academic Development, 1 (1): 3-5.

Ndlovu-Gatsheni, S. J. 2013. Why decoloniality in the 21st century. The Thinker, 48:.10-15.

Ndlovu-Gatsheni, S.J. 2015 "Decoloniality as the Future of Africa”. History Compass, 13 (10): 485-496

Pink, S. (2013). Doing Visual Ethnography (3rd ed.). London: Sage Publications. Prinsloo, E..H. 2016. The role of the Humanities in decolonising the academy. Arts and Humanities in Higher Education, 15(1): 164-168.

Randall, W. L., Clews, R. and Furlong, D. 2015. The Tales that Bind: A narrative model for living and helping in rural communities. Toronto: Toronto University Press.

Ritchie, J., \& Spencer, L. 1994. Qualitative Data Analysis for Applied Policy Research. In R. Burgess (Ed.), Analyzing Qualitative Data (Vol. 173-194). London: Sage. Roberts, P. besides Green, B. 2013. Researching Rural Places: On Social Justice and Rural Education. Qualitative Inquiry. 19 (10): 765-774 Rohleder, P. and Thesen, L. 2012. Interpreting drawings: reading the racialised politics of space. In B. Leibowitz, L. Swartz, L. Nicholls, P. Rohleder, V. Bozalek and R. 
Carolissen (Eds.), Community, self and identity: educating South African university students for citizenship Cape Town: HSRC Press. 87-96)

Scott, I., Yeld, N., and Hendry, J. 2007. Higher education monitor No.6: A case for improving teaching and learning in South African Higher Education. The Council on Higher Education, Pretoria.

Statistics South Africa. 2003. Census 2001: Investigation into appropriate definitions of urban and rural areas for South Africa: Discussion document. Retrieved 27 May 2019, from http://www.statssa.gov.za

Stokes, Helen, Stafford, John and Holdsworth, Roger n.d. Rural and remote school education: A survey for the human rights and equal opportunity commission. Youth Research Centre, University of Melbourne.

Timmis, S. and Williams, J. 2013. Students as co-researchers: a collaborative, community-based approach to the research and practice of technology enhanced learning. In E. Dunne and D. Owen (Eds.), The Student Engagement Handbook, Practice in Higher Education (pp. 509-525). Bingley, UK: Emerald.

Timmis, S., Yee, W. C.and Bent, E. 2016. Digital Diversity and Belonging in Higher Education: A Social Justice Proposition. In E. L. Brown, A. Krasteva and M. Ranieri (Eds.), International Advances in Education: Global Initiatives for Equity and Social Justice: Volume 10. E-learning \& Social Media: Education and Citizenship for the Digital 21st Century. Charlotte, N.C.: Information Age Publishing. Townsend, L. and Weiner, G. 2011 Deconstructing and reconstructing lives: auto/biography in educational settings. London, Ontario. Althouse Press. Wa Thiong'o, Ngũ g1 i 1994. Decolonising the Mind: The Politics of Language in African Literature. Heinemann Educational. 
wa Thiong’o, Ngũ g1 2009. Something Torn and New: An African Renaissance. New York. Basic Civitas Books.

Walker, M. and Mathebula, M. 2019 "Low-income youth migrating to urban universities in South Africa: opportunities and inequalities". Compare DOI 10.1080/03057925.2019.1587705.

Walker, M. and Mkwananzi, F. 2015 Challenges in accessing higher education: a case study of marginalised young people in one South African informal settlement. International Journal of Educational Development, 40: 40-49 Webbstock, D. 2017 Decolonising the curriculum: stimulating debate. Council for Higher Education

Wilkins, D.A. 1976. Notional syllabuses. London: Oxford University Press. 